\title{
Authenticity as a compromise: a critical discourse analysis of Sámi tourism websites
}

\section{Cecilia de Bernardi}

To cite this article: Cecilia de Bernardi (2019): Authenticity as a compromise: a critical discourse analysis of Sámi tourism websites, Journal of Heritage Tourism, DOI: 10.1080/1743873X.2018.1527844

To link to this article: https://doi.org/10.1080/1743873X.2018.1527844

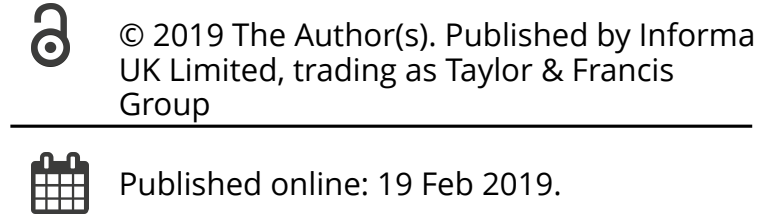

Submit your article to this journal $\square$

Џll Article views: 33

View Crossmark data ¿ 


\title{
Authenticity as a compromise: a critical discourse analysis of Sámi tourism websites
}

\author{
Cecilia de Bernardi (iD * \\ Faculty of Social Sciences, Multidimensional Tourism Institute, University of Lapland, Rovaniemi, Finland
}

\begin{abstract}
Authenticity is considered a very important means to attract tourists. Different enterprises and destinations compete for visitors and authenticity is an important factor for visitors' travel decisions. Within the context of indigenous and cultural tourism, several studies have criticized the way in which indigenous and local populations are portrayed in order to attract tourists, since they often involve colonial images and descriptions that are no longer corresponding to the contemporary situation. This study presents an alternative perspective on the discussion on tourism marketing in relation to authenticity. Through critical discourse analysis and retroduction, this study has analysed the websites of Sámi tourism companies from Sweden. The discussion put forward in this study is not a generalizing picture of how the Sámi peoples choose to market themselves, but it problematizes how these particular enterprises relate to issues of authenticity in the representation of cultural heritage. This paper also presents a new approach to authenticity seen as a compromise. The results of this study present one side of a multifaceted discussion on the struggle between different discourses on representations and authenticity that are often the main channel to reach and attract potential visitors.
\end{abstract}

\section{ARTICLE HISTORY}

Received 4 December 2017 Accepted 16 September 2018

\section{KEYWORDS}

Indigenous tourism; Sami; authenticity; retroduction; critical discourse analysis

\section{Introduction}

The Sámi are one of the indigenous populations of Europe. They live in a territory that extends over Norway, Finland, Sweden, and Russia. Although the exact Sámi population is not known, the International Work Group for Indigenous Affairs (http://www.IWGIA.org) estimates it to be between 50,000 and 100,000. Their territory is collectively called Sápmi. The Sámi also speak different languages in various regions, which are not always mutually understandable. There are other substantial differences between Sámi located in different areas. As Müller and Viken (2017, p. 3) argue: 'Tourism is basically founded on differences.' The Sámi in Scandinavia have been involved in tourism for many decades, with both negative and positive effects: 'Indigenous tourism is not necessarily a strong and emancipating industrial or societal development factor' (Müller \& Viken, 2017, p. 4). A few examples of issues involving tourism are marketing representations (e.g. Niskala \& Ridanpää, 2016; Olsen, 2006; Saarinen, 1999), disturbances from tourists (Pettersson \& Viken, 2007) and the use of Sámi culture in the tourism industry, especially in Finland (Pettersson, 2004, p. 25). The Sámi are also involved in several local and international political processes to affirm their rights as an indigenous population (http://www.IWGIA.org). 
In the process of increased travelling and globalization, local populations can become subordinate to tourism projects, which are often based on a mediated feeling of tradition (Selwyn, 1996). The Sámi have been involved in this process, reconstructing and representing their culture every year during the popular festival in Jokkmokk, Sweden (Müller \& Pettersson, 2006). When an indigenous population presents its culture in the context of tourism, the attractive aspects are usually different cultural traits. Tourists search for different cultures and kinds of nature (Müller \& Viken, 2017), and they have expectations of seeing such things (Müller \& Kuoljok Huuva, 2009; Olsen, 2006; Viken, 2006), which can be influenced by marketing (Costa, 1998; Niskala \& Ridanpää, 2016; Schellhorn \& Perkins, 2004). In tourism advertising and promotion, the image of indigenous populations and the concept of authenticity are often driven by travel literature, which may be influenced by otherness, as is true for the Sámi (Saarinen, 1999). In the end, tourists celebrate otherness (Viken \& Müller, 2017).

This paper first shows the conceptualizations of authenticity and heritage relevant for this study. The methodology is then discussed, followed by a presentation and problematization of the analysed data. From the data and the previous research on heritage, Sámi tourism and authenticity, the paper then draws conclusions on the Sámi's representations of their own heritage, and how these are related to more comprehensive discourses on heritage and authenticity. This paper is the result of a constant hermeneutical interpretation (through retroduction and critical realism) between the results of the critical discourse analysis, previous research, and the constantly growing body of research regarding authenticity and the Sámi.

This paper's main goal is to explore a new conceptualization of authenticity based on compromise, through analysing Sámi-produced promotional tourism websites. This is done using a new approach - retroduction and critical discourse analysis. This combination gives an account of the discourses surrounding producing marketing material in the context of tourism.

This paper's novelty is the fact that it compares tourism marketing representations that indigenous people have created to promote themselves to literature that analyses representations produced by third parties. Examples of the latter include: Official websites used by travel agents (Choi, Lehto, \& Morrison, 2007; Echtner \& Prasad, 2003), printed material for the international market (d'Hauteserre, 2011), or representations to promote a theme park (Magnoni, Ardren, \& Hutson, 2007). There are some studies that have already taken into consideration indigenous populations' own creation of promotional material (Fonneland, 2013; Olsen, 2008) or material produced in cooperation with them (Keskitalo \& Schilar, 2017). Olsen's study (2008), which is similar to the one proposed in this paper, analyses Maori-produced brochures. This study broadens the scope of this kind of research by taking into consideration several Sámi companies. Furthermore, this paper also presents a new conceptualization of authenticity related to compromise and broadens the scope of the research regarding indigenous tourism. Whitford and Ruhanen (2016, p. 1091) analysed indigenous tourism research and found that indigenous tourism research should be more iterative, adaptive and flexible' in style and that stakeholders should participate in the research process. Research should also focus more on the process of creating indigenous tourism and involving indigenous populations. This paper follows these recommendations. The companies whose websites are presented in this research have been contacted by the researcher.

\section{The Sámi and tourism}

The Sámi people are usually represented by certain defining cultural markers that are also meant to create difference and entice potential visitors. Some examples include traditional activities, traditional tents or huts, traditional costumes, and reindeer herds (Viken \& Müller, 2017). Generally, markers that are used for promoting indigenous populations are related to 'religion, dance, and architecture' (Silver, 1993, p. 304), while the people themselves are represented as primitive. The level of industrialization of the country in which they live is hidden from the promotional messages. Furthermore, cultures are shown as 'timeless and unchanging' (Silver, 1993, p. 304). This is also an 
important aspect of the 'quest for authenticity' (MacCannell, 1973). This representation gives an image of native populations as just there for tourists' consumption (Silver, 1993). As an example, the Sámi expressed their discomfort over being photographed by tourists, even when they were just going about their daily lives wearing traditional Sámi clothing (Pettersson \& Viken, 2007).

Tourism is also a way for the Sámi to re-negotiate their identities (Tuulentie, 2006). They are conscious of their choice to diversify themselves as a way to attract tourists, as can be argued for other indigenous populations (Viken \& Müller, 2017). Tourism is also mostly welcome and seen as 'a path to modernity and economic development' (Viken \& Müller, 2017, p. 21). Representations related to otherness are also 'challenged and resisted' (Selwyn, 1996, p. 10). As long as the local and indigenous populations have control of their representations and tourism activities involving their cultures, they can represent themselves and their culture as they see fit. However, the development of tourism in Scandinavia is controlled by nonindigenous institutions and DMOs (Destination Marketing Organizations) (Viken \& Müller, 2017). The Sámi are also divided about their community's role in tourism, since some see the advantages of commercialization, while others see it as a threat (Pettersson \& Viken, 2007).

Cultural commoditization or commercialization is another important issue. One example is whether or not to adapt certain types of cultural expressions (such as the Sámi knife and special cups, called guksis) for tourism purposes (Viken \& Müller, 2017). The general argument is that commoditization brought by tourism potentially sabotages local cultures. For example, traditional dances and costumes can become commodities for tourists (Cohen, 1988). As Selwyn (1996) argued, the discussion has mainly focused on the fact that commoditization leads to dependency, but this is quite a simplistic way to see things. Cultural exchange has resulted in the creation of other spheres of activity that have demonstrated autonomy, and the festival in Jokkmokk is an example of this (Müller \& Pettersson, 2006). Furthermore, commercial development can be a way to do business and sustain the operations of the companies (Viken \& Müller, 2017).

\section{Authenticity, heritage and tourism}

Heritage tourism is described as a widespread and old type of travel. Heritage is defined as 'presentday use of the past' (Ashworth, 2003; as cited in Timothy \& Boyd, 2006, p. 2) and is also connected to political and economic concerns. There is also an issue of authenticity, such as, when tourists visit sites they believe to be authentic and want to have 'authentic encounters' (Timothy \& Boyd, 2006). Tourism related to heritage includes travelling to sites where cultures can be observed. Timothy and Boyd (2006) advocated for studying the supply side of heritage tourism, which this paper addresses by looking at indigenous tourism related to Sámi heritage and culture. Indigenous tourism has been defined as 'tourism activities in which indigenous people are directly involved either through control and/or by having their culture serve as the essence of the attraction' (Hinch \& Butler, 2006, p. 5). As previously mentioned, tourists often seek authenticity when travelling, which this is also the case for indigenous tourism. This is why it is important to also problematize the supply side of this kind of tourism.

The study of the concept of authenticity is long and diverse. Today, it is mainly about multiple authenticities, rather than only one. There are also many different definitions of authenticity. MacCannell (1973) and Cohen (1988) are two important contributors to this area of research, and Selwyn (1996, p. 6) described the question of authenticity as unresolved, which is still the case nowadays. MacCannell (1973) described it as the reason why tourists travel to some places, while Cohen (1988, p. 374) noted that staged authenticity satisfies tourists' quests for authentic experiences because they search for the 'pristine, the primitive, the natural, that which is as yet untouched by modernity.'

Pearce and Moscardo (1986) proposed an approach to authenticity based on the person and how authenticity could be achieved through different kinds of interactions with places, people or both. Along this same path, Wang (1999) proposed the conceptualization of existential authenticity. 
His discussion was based on previous conceptualizations, such as objective (something is either authentic or not) and constructive (authentic is what the visitor perceives as such) authenticities. Existential authenticity is based on 'the existential state of being' that visitors may perceive during touristic activities (Wang, 1999, p. 359).

Authenticity has also been conceptualized as a performance. Therefore, authenticity is neither objective nor subjective, but performative (Zhu, 2012). This type of authenticity is an alternative solution to too objective or too subjective conceptualizations of authenticity. The authenticity of the place is related to the interaction between people, and between people and objects (Knudsen \& Waade, 2010). Zhu (2012) argues for a different perspective on performativity; namely that authenticity is related to a connection between heritage and one person's life experiences. To reproduce a ritual for tourism purposes becomes a way to perform identity, as previously mentioned in the case of the Sámi (Tuulentie, 2006). This is a starting point from which to analyse the achievement of authenticity in a particular context (Zhu, 2012). As previously mentioned, promoting tourism can create situations in which the local and indigenous populations are subjects of otherness.

Authenticity is one very influential aspect of this process. Selwyn (1996, p. 28) argues that the myths that are created in the context of tourism are on one hand, characterized by authenticity, while on the other, they are influenced by 'historical, economic and political constructions.' In contrast, Steiner and Reisinger (2006) describe how staging a certain representation for locals may, in fact, be a form of authenticity. The argument that tourism is the sole agent of change, and that the hosts are not able to be agents of change, is in itself, a way to take power from the local population and deprive them from possibly defending themselves (Steiner \& Reisinger, 2006).

According to Ram, Björk, and Weidenfeld (2016), there is a connection between tourists' perceptions of a place as authentic and their attachment to it. This also relates to the results of the study by Ivanovic (2014), which empirically shows how history, heritage and 'authentic properties' (p. 512) are positively associated to tourists' experiences. The fact that tourists perceive a place as authentic conveys a sense of value to them. Tourists are not the only ones assigning value to authenticity. Even in the case of UNESCO, there are criteria for authenticity in the requirements for World Heritage Sites (Wang, Huang, \& Kim, 2015). Authenticity in this case is the 'cultural value, as well as its value as truthful and credible "information source" (Wang et al., 2015, p. 1469). One concrete example of this was a complaint in an evaluation protocol by the IUCN (International Union for Conservation of Nature) related to the Sámi using mobile phones on the Sjaunja nature reserve. Use of the mobile phones was seen as damaging for the integrity of the environmental sustainability of the area' (Green, 2009, p. 87). As Green argues, a mobile phone is hardly a threat to the environment, but it does not really match with a stereotypical way to see the Sámi and how they should act (2009, p. 87). The studies presented here not only show that authenticity is an important factor for tourists and institutions, but also the harmful effects of the far-reaching authenticity discourse.

\section{Authenticity as compromise}

This discussion of relevant literature on authenticity has shown that institutions (such as UNESCO) and tourists make this concept important. It is also clear that there is a very close connection between tourism, authenticity, and heritage. The effects of discourse on authenticity were also introduced. This study contends that previous conceptualizations of authenticity are problematic, since they are based on assumptions that are either too objective or too subjective.

Taylor (2001) has argued for sincerity instead of authenticity, and connects it to performance of culture. He discusses authenticity based on time and the fact that indigenous populations are seen as different because they are also seen as timeless. He argues that realistic views of authenticity are based on criteria spread by marketing. He also quotes MacCannell (1992, pp. 27-35), who describes how combining modernity with traditional aspects of a culture is just another negative aspect of modern economic relations. People are not primitive anymore, but they act as such for economic gain. Taylor (2001, p. 13) asks a very relevant question as to who should 'hold the power to define the authenticity 
of a cultural experience?' To answer this question - the power should be in the hands of the indigenous populations, for which this new conceptualization of authenticity advocates. Taylor (2001, pp. 11-15) also differs from MacCannell by arguing that even in cases of staged authenticity, those who are performing their culture have an interaction with the tourists that is relevant to their identity, as previously mentioned in the case of the Sámi. Taylor (2001) also mentions that interaction with tourists is a possibility for the Maori to address stereotypes.

In this paper, a new way to conceptualize authenticity based on compromise is presented. However, the term authenticity will be used, rather than sincerity. The reason is that one suggested solution to the issues related to authenticity could be to instead introduce sincerity (Taylor, 2001). However, it is not possible to fully address this issue in this paper. The main point is not which word is used, but the essence of the terms, which are recognized and searched by both tourists and institutions. In other words, making a division between authenticity and sincerity does not solve the problem of how to define and conceptualize authenticity. In this paper, it is also not possible to address authentication, which has been recently proposed as another possible solution to the above-mentioned debate (Mkono, 2013).

Authenticity as a compromise is based on the work of Wilson (2014), who discusses authenticity from a critical realist viewpoint. Different social structures can affect if we can be authentic to ourselves regarding our ideas and our actions as concrete individuals, such as working in a capitalist setting. Wilson shows how authenticity should be conceptualized in terms of doing, making, and agency. This has been previously argued regarding performance of heritage in the context of tourism (Zhu, 2012). The description of authenticity is discussed using the situation of Early Music musicians' struggle with authenticity. On the one hand, producing Early Music must be historically faithful, but also a personal performance. The solution is a compromise between these two aspects (Wilson, 2014).

A view of authenticity based on compromise allows for principles of authentication to be applied, as well as leaving room for subjective interpretations and a certain performance of one's heritage. The compromise is also expressed in the practical situation of Sámi tourism entrepreneurs, which are often a constant fluctuation and contain conflicts related to their private lives, their belonging to the Sámi community (with its social and political implications), and their role as reindeer herders (Åhrén, 2008; Leu \& Müller, 2016; Tuulentie, 2006; Viken, 2006). Furthermore, they are also engaged in conflicts regarding the involvement of their heritage in tourism and varying opinions about it (Pettersson \& Viken, 2007).

\section{Methods}

This research applied retroduction to the study of representations of indigenous populations. Retroduction is a possible solution to conflicts regarding cooperating with indigenous populations in matters of scientific inquiry and indigenous knowledge (Price, 2005). Retroduction is 'a mode of inference, by which we try to arrive at what is basically characteristic and constitutive of [the] structures' (Danermark, Ekstrom, Jakobsen, \& Karlsson, 2002, p. 96). These social structures are involved in the interplay that constitutes social reality at a more abstract level, together with more concrete, everyday manifestations (Fairclough, 2010, pp. 231-232) that are present in every interaction. For instance, tourism marketing is shaped by structures that are more abstract, but become concrete in the production of marketing material and its consumption by tourists.

As critical realism postulates the existence of things behind our perceptions of the world, retroduction is about moving from what is empirically observable to the structures that are not immediately observable (Danermark et al., 2002, p. 96). This usually involves identifying patterns. For instance, certain discourses can be more effective than others in convincing some version of the 'truth' (Ackroyd \& Karlsson, 2014, p. 18).

This paper also implies that these representations are based on a certain underlying objectivity, as concrete objects or ideas that are represented (Cashell, 2009). The main assumption is that discourse 
cannot refer to itself, but must be about something else (Bhaskar, 1993, p. 212; as cited in Cashell, 2009, p. 157).

In this study, critical discourse analysis (CDA) based on retroduction is used to map the relationships between authenticity, tourism marketing, and Sámi cultural heritage. Heritage is conceptualized as both tangible and intangible aspects that unite a group. It is also seen as adapting, changing and growing, as well as being connected to the past (Edson, 2004; Waterton, Watson, \& Silverman, 2017). The term critical comes from the fact that CDA's focus is unequal relationships, at the same time as it strives to provide explanations and solutions to overcome these relationships (Fairclough, 2010, pp. 231-232).

Fairclough's approach stems from the analysis of a social problem and is about finding possible obstacles and solutions to it (2010, pp. 234-239). The general marketing representation of the Sámi and other indigenous populations is problematic (e.g. Amoamo \& Thompson, 2010; Niskala \& Ridanpää, 2016; Olsen, 2006; Saarinen, 1999; Waitt, 1999), but the Sámi can portray themselves and their culture in the way they deem best. However, they are all individuals with different opinions on tourism and the role of Sámi culture within it. Therefore, it is relevant to analyse the representations that the Sámi themselves have created to discuss the themes that they see as important to attract tourists. Furthermore, studying the underlying mechanisms and structures that make these themes relevant will give us a deeper knowledge into the Sámi’s own views on touristic promotional material, considering that Sámi culture is often presented in tourism marketing.

The analysis is based on semiotic material that is analysed under the lenses of different theories. This kind of study implies a certain degree of linguistic analysis to demonstrate the interpretations made from the data by establishing connections to different genres and styles (Zotzmann \& O'Regan, 2016). Discourses are different 'ways of representing a part of the world from a particular perspective' (Zotzmann \& O’Regan, 2016, p. 116), genres are different interactions (such as create a webpage) and styles are ways of being (such as one's role as an entrepreneur). It is also very important to consider interdiscursivity by connecting the analysis of the text to the analysis of the structures (Zotzmann \& O’Regan, 2016).

\section{The empirical material}

The research material were the representations of Sámi cultural heritage on the websites of eight Sámi tourism enterprises from Sweden that clearly state in the company description that they are Sámi. The examined sections of the websites were analysed in Swedish and the wordings used were later translated into English in order to investigate them in the original language in which they were written. Websites are sometimes quite comprehensive, so it would exceed the scope of this study to analyse them in their entirety. The chosen sections for analysis were the main page, the potential landing page for potential visitors when visiting the website, and other relevant pages describing offered activities and/or the company, depending on the structure of the website and its content (some websites present most of the information on the main page, while others have very detailed subsections). Pictures were also considered and described to ensure a complete analysis of the website's content. Although the analysis was not quantitative, it sought to be balanced. The companies that were analysed were informed of this research ,and the information was anonymized because not all companies agreed to have their name displayed.

\section{Results}

Fairclough's (2001, p. 125) methodology starts by identifying a problem and obstacles to its solution. In this case, the problem comprises the representations that generally dominate tourism marketing, and the obstacle is the wide distribution of these representations. The next step was to analyse the network of practices and the relationship to the particular practice. Retroduction also involves identifying patterns, so the researcher started by reading the text and looking at the pictures on the 
websites of interest. This revealed patterns that were also present in other studies on tourism marketing. This was not a linear process since the author went back and forth between the websites and the literature to look for similarities and discrepancies. The websites showed clear patterns that were also present in a representative study of brochures produced by members of the Maori population and in many other independent studies regarding the Sámi and other indigenous populations (Olsen, 2008). The most prominent themes that emerged during the analysis were:

- Theme 1: Connection to nature/harmony with nature/peacefulness (Bruner, 1991; Fennell, 2008; Olsen, 2006; Prebensen, 2007; Waitt, 1997), particularly connection to untouched nature (e.g. Echtner \& Prasad, 2003; Pashkevich \& Keskitalo, 2017; Prestholdt \& Nordbø, 2015).

- Theme 2: Connection to reindeer (Müller \& Pettersson, 2006; Niskala \& Ridanpää, 2016; Olsen, 2006; Viken, 2006; Vladimirova, 2011).

- Theme 3: Connection to the past (Müller \& Pettersson, 2001; Niskala \& Ridanpää, 2016; Saarinen, 1999; Viken, 2006; Vladimirova, 2011).

- Theme 4: The use of friendly language (Kalmane, 2010, pp. 77-78; Vahid Dastjerdi, DavoudiMobarakeh, \& Zare, 2012).

- Theme 5: Authenticity as a noun or adjective (Sharma, Jackson \& Inbakaran, 2008; Yeoman, Brass \& McMahon-Beattie, 2007).

- Theme 6: The Sámi costume (Müller \& Pettersson, 2001; Niskala \& Ridanpää, 2016), Sámi huts or tents (Pettersson, 2002), and traditional singing connected to indigenous populations or the traditional Sámi yoik chant (Waitt, 1997, 1999; Bruner, 2001; Pettersson, 2002; Vladimirova, 2011).

- Theme 7: Joining the Sámi (Amoamo \& Thompson, 2010; Keskitalo \& Schilar, 2017; Santos, Belhassen, \& Caton, 2008).

- Theme 8: Modernity and useful information for tourists (Müller \& Pettersson, 2001; Olsen, 2008; Overend, 2012; Silvén, 2012; Viken \& Müller, 2006).

These themes function as an interpretation key for the texts and pictures on the websites. The next phase of Fairclough's (2001) approach is analysing the discourse itself and its relationship to structures, other discourses, and language. Table 1 summarizes these results to simplify the presentation of the data. Each instance identified on the websites was connected to one of the themes and given a general title describing what was presented in either text or picture, or both. These connections were not meant to be neutral, but were the interpretations made by this researcher's particular point of view, mediated by previous research. If the texts mentioned nature in relation to the company or Sámi culture, this phrase was categorized in Theme 1 . Since this is not a quantitative study, there is no indication if the reference to a theme was present on a website only once or several times. The only times in which themes were repeated is when one instance is very different from another, such as a mention of both the traditional hut and the costume.

\section{Discussion}

The summary of the collected textual and pictorial instances (Table 1) shows that certain themes are more common than others. As Olsen (2008) illustrated, the theme of modernity, which was shown in all of the websites, can be found together with more traditional elements, such as the connection to (untouched) nature, and to peace and harmony, which were also present in all of the websites. The language for addressing tourists is usually friendly, expressed in the use of imperative form ('Follow us!' 'Join us!'), but the capitalization of the word $\mathrm{Ni}$ (plural form of the personal pronoun you in Swedish) could express a form of distancing from tourists and also a form of respect that is reminiscent of some colonial sentiment, since it is not otherwise often used. Only three websites used this form of language.

Three websites explicitly mentioned a connection to nature in their text, but seven of eight company websites contained images related to untouched nature in videos or pictures. As Table 1 shows, 
Table 1. Itemization of selected web pages and thematic instances.

Website 1 (Page describing the company)

Website 2 Page describing the company)

Website 3 (Page describing the company)

Website 4 (Page describing the company)

Website 5 (Main page - same as company description + activities)

Website 6 (Page about the company)

Website 7 (Main page - same as company description + activities main page)

Website 8 (Page about the company)
Use of 'you' plural with capital letter for respect (theme 4)

Calmness of the place/Enjoy the silence/phones don't work (theme 1)

Reindeer in text and pictures (theme 2)

Mention of the hut (theme 6)

Traditional costume in pictures (theme 6)

Expressions about doing things together (theme 7)

Pictures of the family/mention of work outside of herding (theme 8)

Word authentic (theme 5)

Word calm (theme 1)

Use of old name used to describe a Sámi settlement (theme 3)

Reindeer in text and pictures (theme 2)

Mention of modern Sámi cuisine and Sámi institutions (theme 8)

Talk to the tourists directly. 'you' singular but capital for respect (theme 4)

Reindeer in text and pictures (theme 2)

Magnificent nature (theme 1)

Cooperation mentioned with other institutions (theme 8)

Description of the past of the area (theme 3 )

Use of 'you' plural with capital letter for respect (theme 4)

Magnificent nature/harmony/images of nature with a romantic undertone/ company in the middle of nature (theme 1)

Verb used: harmonise (theme 1)

Romantic past: people didn't lock their doors (theme 3)

Reindeer in text and pictures (theme 2)

The yoik mentioned (theme 6)

Mention of cooperation/only modernity shown in pictures/ mention of modern Sámi cuisine (theme 8)

The text talks directly to the reader (theme 4)

Campfire association to Sámi culture (theme 5)

Activities offered are in peace and harmony with nature (theme 1)

Old stove (theme 3 )

Reindeer in text and pictures (theme 2)

Description of the hut present (theme 6)

Join the everyday life (theme 7)

Separation from the Sámi in the past/no costume (theme 8)

Verbs to follow with/to discover (theme 4 and theme 7)

Connection to nature and ecotourism (theme 1)

Reindeer in text and pictures (theme 2)

Sámi costume and Sámi hut (theme 6)

Talk of Sámi modernity and Sámi institutions (theme 8)

Imperative form such as 'follow us/come with us' (theme 4)

Sámi doing things as in the past (theme 3)

Reindeer in text and pictures (theme 2)

Sámi costume in pictures (theme 6)

Picture hinting to join connected to food and fire (theme 7)

Mention of Sámi institutions/pictures showing modernity/mention of cooperation/mention of contemporary Sámi activities (theme 8)

Entrepreneurs refer to themselves as ' $w e^{\prime}$ (theme 4 and theme 7)

Authentic objects available there (theme 5)

Magnificent land (theme 1)

Connection to nature (theme 1)

Yoik (theme 6)

Join in the everyday life (theme 7)

Aspects of modern Sámi life as entrepreneurs (theme 8)

the concept of something untouched is often presented in tourism marketing, regarding both nature and the Sámi (Pettersson, 2004). Untouched nature is meant to attract tourists, but in relation to the Sámi, it is interpreted as a way for them to construct their culture (Valkonen \& Valkonen, 2014). Associating the Sámi with untouched nature can also underline the presence of wilderness and the Sámi populations associated with it. Table 1 also includes the category of being in harmony with nature, which is another trait that is often associated with the Sámi and other indigenous populations in tourism marketing. The same can be said about the word peaceful, which is often associated with both destinations and people in tourism marketing. Expressions related to peace, calm and a 
connection to nature can be found in almost all of the websites, while more than half of the analysed companies showed a connection to the past. As the literature mentioned in Table 1 shows, the Sámi are often associated to the past. These images are connected to romantic images presented not only in other types of marketing material, but also in historic literature and media representations of the Sámi (Valkonen \& Valkonen, 2014).

Reindeer herds were either textually or visually shown in all but one website. The question of associating reindeer with the Sámi is multifaceted. This connection is quite prevalent in tourism marketing in both Nordic countries (Niskala \& Ridanpää, 2016) and Russia (Vladimirova, 2011). Furthermore, the Sámi are the only people allowed to herd reindeer in Sweden (Josefsen, 2007). This must be taken into consideration when discussing reindeer herds related to the Swedish Sámi. The reindeer herds are a very important aspect of Sámi culture. They represent a means of sustenance and a symbol that often represents Sámi culture in tourism marketing. Another important aspect to consider is the fact that not all Sámi who are legally allowed to herd reindeer actually choose to do so.

Three of the company websites showed traditional Sámi clothing, three showed Sámi huts or tents, and two mentioned traditional yoik singing. The Sámi are often represented in their traditional clothing, in the context of tourism marketing (Table 1). However, there are problems with this, such as tourists taking pictures of the Sámi when they are performing everyday tasks (Pettersson \& Viken, 2007). The Sámi hut is also at the centre of tourism marketing for the countries in which the Sámi live. It was also mentioned as part of the activities Sámi entrepreneurs offer (Pettersson, 2002). All the companies also took great effort to show Sámi modernity, such as pictures of the Sámi in everyday clothing or using modern technology, such as snowmobiles and mobile phones. They also describe different cooperations with other actors or institutions. Five websites showed a connection to the Sámi past and historical roots.

The least-used theme involved the word authenticity as either an adjective or a noun (only three websites contained the explicit word). There can be multiple retroductive interpretations for this. It may not be necessary to call something authentic because its representation comes from a Sámi company, making it authentic. Another possible interpretation is a conscious refusal to use a word used in marketing (Taylor, 2001). The word authentic could also paradoxically draw attention to the possibility that some aspects of the culture might be inauthentic and undermine the reader's trust in the cultural portrayal that is presented. This conceptualization of authenticity will be discussed in future phases of this research.

\section{Conclusions}

In the context of this analysis, web pages from eight Sámi tourism companies were analysed to understand how authenticity is structured in the context of tourism marketing and argue for its relationship to a novel conceptualization of authenticity based on compromise.

The last phases of Fairclough's (2001, p. 125) critical discourse analysis framework consider why the social order must address the encountered problem. The instances presented and discussed here are not necessarily problems to be solved or obstacles to overcome, but it is clear from this analysis that there are certain recurring themes that the Sámi use, which are also commonly used elsewhere in tourism. As Viken and Müller (2017) argue, indigenous tourism is not neutral, as its activities are strongly influenced by politics, economy, and ideology. Its language and expressions were analysed and connected to the underlying discourse concerning indigenous populations in tourism marketing. The analysis also shows characteristics that are particularly connected to the situation of indigenous populations in modern times.

This paper argues that modern and traditional aspects of Sámi culture are an expression of an evolving heritage and identity. As Laven (2015, p. 176) contends: 'Heritage development can be a constructive, empowering force for enhancing community-level resilience.' Heritage is not something static that can be preserved. Sámi culture is very much alive. Film festivals, art installations, 
activism, fashion and music celebrations are only one small aspect of an extremely varied and active cultural Sámi life. Heritage is also adaptive (Edson, 2004) and, similar to authenticity, is connected to agency and doing. The retroductive idea of compromise best explains the characteristics of the discourse in tourism websites on Sámi culture.

This paper's analysis of the themes identified in the websites and common themes presented in other marketing websites produced by both indigenous and non-indigenous populations can be interpreted in several ways. Olsen (2008) saw it as an instance of self-orientalism, in which indigenous people present themselves as the colonial powers would. Another interpretation is that the overlying social structures do influence tourism marketing in relation to otherness and authenticity, but that there are also resistance and change driven by the Sámi entrepreneurs.

The tourism discourse identified in marketing is based on a set of binary oppositions between modernity connected to alienation and authenticity (Olsen, 2008). The social structures present in the context of tourism influence the content of these websites, but the themes also show clear connections to Sámi cultural heritage, conceptualized through certain concrete and abstract markers that potential visitors recognize. As previously discussed, representation is grounded in reality, and discourse cannot be about itself. The connection to nature, reindeer herds, and traditional clothing are part of Sámi culture. The representations of these websites all have certain themes in common, so this analysis shows some underlying conceptualization of Sámi culture, represented by certain markers. They show dynamic cultural development, in which there are clear historical connections but also many modern traits. Tourists are looking for difference. This is also why some of the themes described here are needed in the social order (Fairclough, 2001, p. 125). Showing difference is the selling point that makes these companies unique in the general tourism market. There can be a division on the use of culture, mentioned in the previous section, in which some see the advantages of commercialization, while others see it as a threat.

Members of the Sámi population's representation of Sámi heritage and dialogue with the people behind the Sápmi Experience label (International Ecotourism Society, n.d.) should be the basis for national and regional tourism marketing of Sápmi, particularly regarding both national and international agencies and guides. The previously described issues regarding the problems the Sámi have with the presentation of their culture and heritage can only be avoided if they are involved. As Keskitalo (2017, p. 35) noted, there is reason to wonder if 'more accurate points of representation could be found to address this multiplicity of both areas and peoples.' This does not mean that even if the Sámi participate in producing marketing material, the results will be accepted by most of the Sámi population. Rather, including the Sámi in designing new material starts to give them a voice in a process from which they have often been excluded. This is also a way past the obstacles Fairclough (2001, p. 125) mentioned, which were identified in the context of general tourism and indigenous tourism marketing.

Authenticity can be conceptualized as compromise based on the analysed texts because of different aspects. The website as a genre usually contains short bits of text and pictures, making it difficult to balance correct information with attractive messages. Furthermore, without the markers that tourists seek, there may be no visitors to the website. However, all of the companies want to show authentic Sámi heritage by stressing certain links to tradition, but at the same time show that the Sámi have a modern life. This connects to the everyday struggles of Sámi life, including their political struggle, their fight against stereotypes, and tourism as a way to celebrate Sámi heritage (Tuulentie, 2006). The themes also show how Sámi entrepreneurs conceptualize authenticity and why they reject previous conceptualizations. Too much subjectivity can lead to too much dispersion and possible loss of cohesion in the Sámi community. If the conceptualization is too objective, it can lead to conflicts over who gets to decide what is authentic. Authenticity as a compromise allows for adopting several viewpoints, such as performance, and heritage, as well as a certain degree of authentication that provides a more ethical use of Sámi culture in tourism. This perspective on authenticity is a middle ground between historical and cultural accuracy, and individual expression. This compromise is made in light of the underlying discourses surrounding Sámi cultural representations and tourism 
in general. The label Sápmi Experience (http://www.fjallhasten.se/sapmi-experience/) created and controlled by members of the Sámi population, is an expression of this compromise.

The last phase of Fairclough's (2001, p. 125) framework is a general reflection on the whole analysis. This study has attempted to achieve a well-rounded discussion of the marketing themes that are present on Sámi websites. Pictures, texts, and general discourses were analysed to show that there are structures that underlie all tourism marketing, both Sámi and non-Sámi. The descriptions that Sámi entrepreneurs publish on their websites can be connected to a characterization of authenticity as a compromise, in which the Sámi must balance several aspects of their lives. As tourism entrepreneurs, they want to attract visitors and show all the interesting aspects of Sámi culture. However, that is not easy, considering the expectations that marketing discourses can entice in potential customers. In addressing this issue, this study also has limitations. It is missing the entrepreneurs' and local indigenous populations' point of view about what is important to display for marketing purposes. This should be addressed by future research, which is planned for this research project.

\section{Disclosure statement}

No potential conflict of interest was reported by the author.

\section{Notes on contributor}

Cecilia de Bernardi is currently a doctoral candidate at the Centre for Tourism and Leisure Research (CeTLeR) at Dalarna University in Sweden. She is also affiliated with the Multidimensional Tourism Institute at the University of Lapland in Rovaniemi, Finland. Her published research essay, Sámi Indigenous Tourism's Empowerment in Nordic Countries Through Labelling Systems: Strengthening Ethnic Enterprises and Activities, was co-authored by her colleagues, Outi Kugapi and Dr. Monika Lüthje, from the University of Lapland. The essay is included in the anthology, Tourism and Ethnodevelopment: Inclusion, Empowerment and Self Determination, edited by Victor T. King and Ismar Borges de Lima. Cecilia de Bernardi's main research interests are indigenous tourism and issues connected to cultural authenticity.

\section{ORCID}

Cecilia de Bernardi (D) http://orcid.org/0000-0002-1400-0357

\section{References}

Ackroyd, S., \& Karlsson, J. C. (2014). Critical realism, research techniques, and research designs. In P. Edwards, J. O'Mahoney, \& S. Vincent (Eds.), Studying organizations using critical realism: A practical guide (pp. 21-45). New York: Oxford University Press.

Amoamo, M., \& Thompson, A. (2010). (Re)Imaging māori tourism: Representation and cultural hybridity in postcolonial New Zealand. Tourist Studies, 10(1), 35-55.

Åhrén, C. (2008). Är jag en riktig same? En etnologisk studie av unga samers identitetsarbete. Umeå: Umeå University. Bruner, E. (1991). Transformation of self in tourism. Annals of Tourism Research, 18(2), 238-250.

Bruner, E. (2001). The maasai and the lion king: Authenticity, nationalism, and globalization in African tourism. American Ethnologist, 28(4), 881-908.

Cashell, K. (2009). Reality, representation and the aesthetic fallacy: Critical realism and the philosophy of C. S. Peirce. Journal of Critical Realism, 8(2), 135-171.

Choi, S., Lehto, X. Y., \& Morrison, A. M. (2007). Destination image representation on the web: Content analysis of Macau travel related websites. Tourism Management, 28(1), 118-129.

Cohen, E. (1988). Authenticity and commoditization in tourism. Annals of Tourism Research, 15(3), 371-386.

Costa, J. A. (1998). Paradisal discourse: A critical analysis of marketing and consuming hawaii. Consumption Markets \& Culture, 1(4), 303-346.

Danermark, B., Ekstrom, M., Jakobsen, L., \& Karlsson, J. C. (2002). Explaining society: Critical realism in the social sciences. London: Routledge.

d'Hauteserre, A.-M. (2011). Politics of imaging New Caledonia. Annals of Tourism Research, 38(2), 380-402.

Echtner, C. M., \& Prasad, P. (2003). The context of third world tourism marketing. Annals of Tourism Research, 30(3), 660-682. 
Edson, G. (2004). Heritage: Pride or passion, product or service? International Journal of Heritage Studies, 10(10), 333348.

Fairclough, N. (2001). Critical discourse analysis as a method in social scientific research. In R. Wodak, \& M. Meyer (Eds.), Methods of critical discourse analysis (pp. 122-138). London: Sage.

Fairclough, N. (2010). Critical discourse analysis: The critical study of language. London: Pearson Education.

Fennell, D. (2008). Ecotourism and the myth of indigenous stewardship. Journal of Sustainable Tourism, 16(2), 129149.

Fonneland, T. A. (2013). Sami tourism and the signposting of spirituality: The case of Sami tour: A spiritual entrepreneur in the contemporary experience economy. Acta Borealia, 30(2), 190-208.

Green, C. (2009). Managing laponia: A world heritage site as arena for Sami ethno-politics in Sweden (Doctoral dissertation). Uppsala University, Uppsala.

Hinch, T., \& Butler, R. (2006). Introduction: Revisiting common ground. In R. W. Butler \& T. Hinch (Eds.), Tourism and indigenous peoples (pp. 1-12). Amsterdam: Elsevier.

International Ecotourism Society. (n.d.). Sápmi experience label recognizes excellence in authentic and sustainable tourism. Retrieved from http://www.ecotourism.org/news/sápmi-experience-label-recognizes-excellence-authenticand-sustainable-tourism

Ivanovic, M. (2014). The perceived authenticity of iconic heritage sites in urban tourism: The case of constitutional hill, Johannesburg, South Africa. Urban Forum, 25(4), 501-515.

Josefsen, E. (2007). The saami and the national parliaments: Channels for political influence. Gáldu Č́la. Journal of Indigenous Peoples Rights, 2. Retrieved from http://archive.ipu.org/splz-e/chiapas10/saami.pdf

Kalmane, M. R. (2010). Advertising: Using words as tools for selling. Lulu Enterprises UK Ltd.

Keskitalo, E. C. H. (2017). Images of the northern and 'Arctic' in tourism and regional literature. In A. Viken \& D. K. Müller (Eds.), Tourism and indigeneiry in the Arctic (pp. 36-49). Bristol: Channel View.

Keskitalo, E. C. H., \& Schilar, H. (2017). Co-constructing 'northern' tourism representations among tourism companies, DMOs and tourists. An example from jukkasjärvi, Sweden. Scandinavian Journal of Hospitality and Tourism, 17(4), 406-422.

Knudsen, B. T., \& Waade, A. M. (2010). Performative authenticity in tourism and spatial experience: Rethinking the relation between travel, place and emotion in the context of cultural economy and emotional geography. In B. T. Knudsen \& A. M. Waade (Eds.), Re-investing authenticity (pp. 1-19). Bristol: Channel View.

Laven, D. (2015). Heritage development and community resilience: Insights for the era of climate change. In D. C. Harvey \& J. Perry (Eds.), The future of heritage as climate change - loss, adaptation, and creativity (pp. 167179). New York: Routledge.

Leu, T. C., \& Müller, D. K. (2016). Maintaining inherited occupations in changing times: The role of tourism among reindeer herders in northern Sweden. Polar Geography, 39(1), 40-57.

MacCannell, D. (1973). Staged authenticity: Arrangements of social space in tourist settings. American Journal of Sociology, 79(3), 589-603.

MacCannell, D. (1992). Empty meeting grounds [elektronisk resurs]. London: Routledge.

Magnoni, A., Ardren, T., \& Hutson, S. (2007). Tourism in the mundo maya: Inventions and (mis)representations of maya identities and heritage. Archaeologies, 3(3), 353-383.

Mkono, M. (2013). Hot and cool authentication: A netnographic illustration. Annals of Tourism Research, 41, $215-218$.

Müller, D. K., \& Kuoljok Huuva, S. (2009). Limits to Sami tourism development: The case of Jokkmokk, Sweden. Journal of Ecotourism, 8(2), 115-127.

Müller, D. K., \& Pettersson, R. (2001). Access to Sami tourism in northern Sweden. Scandinavian Journal of Hospitality and Tourism, 1(1), 5-18.

Müller, D. K., \& Pettersson, R. (2006). Sámi heritage at the winter festival in jokkmokk, Sweden. Scandinavian Journal of Hospitality and Tourism, 6(1), 54-69.

Müller, D. K., \& Viken, A. (2017). Indigenous tourism in the Arctic. In A. Viken \& D. K. Müller (Eds.), Tourism and indigeneity in the Arctic (pp. 3-32). Bristol: Channel View.

Niskala, M., \& Ridanpää, J. (2016). Ethnic representations and social exclusion: Sáminess in Finnish lapland tourism promotion. Scandinavian Journal of Hospitality and Tourism, 16(4), 375-394. doi:10.1080/15022250.2015.1108862.

Olsen, K. (2006). Making differences in a changing world: The Norwegian Sámi in the tourist industry. Scandinavian Journal of Hospitality and Tourism, 6(1), 37-53.

Olsen, K. (2008). The maori of tourist brochures representing indigenousness. Journal of Tourism and Cultural Change, 6(3), 161-184.

Overend, D. (2012). Performing sites: Illusion and authenticity in the spatial stories of the guided tour. Scandinavian Journal of Hospitality and Tourism, 12(1), 44-54.

Pashkevich, A., \& Keskitalo, E. C. H. (2017). Representations and uses of indigenous areas in tourism experiences in the Russian Arctic. Polar Geography, 40(2), 85-101.

Pearce, P. L., \& Moscardo, G. M. (1986). The concept of authenticity in tourist experiences. The Australian and New Zealand Journal of Sociology, 22(1), 121-132. 
Pettersson, R. (2002). Sami tourism in northern Sweden: Measuring tourists' opinions using stated-preference methodology. Tourism and Hospitality Research, 3(4), 357-369.

Pettersson, R. (2004). Sami tourism in northern Sweden: Supply, demand and interaction (Doctoral dissertation). Umeå University, Sweden.

Pettersson, R., \& Viken, A. (2007). Sami perspectives on indigenous tourism in Northern Europe: Commerce or cultural development? In R. W. Butler \& T. Hinch (Eds.), Tourism and indigenous peoples (pp. 176-187). Amsterdam: Elsevier.

Prebensen, N. K. (2007). Exploring tourists' images of a distant destination. Tourism Management, 28(3), 747-756.

Prestholdt, R., \& Nordbø, I. (2015). Norwegian landscapes: An assessment of the aesthetical visual dimensions of some rural destinations in Norway. Scandinavian Journal of Hospitality and Tourism, 15(1-2), 202-222.

Price, L. (2005). Playing musement games: Retroduction in social research, with particular reference to indigenous knowledge in environmental and health education. South African Journal of Environmental Education, 22, 87-96.

Ram, Y., Björk, P., \& Weidenfeld, A. (2016). Authenticity and place attachment of major visitor attractions. Tourism Management, 52, 110-122.

Saarinen, J. (1999). Representation of indigeneity: Sami culture in the discourses of tourism. In J. N. Brown \& P. M. Sant (Eds.), Indigeneity: Construction and Re/presentation (pp. 231-249). Commack, NY: Nova Science.

Santos, C. A., Belhassen, Y., \& Caton, K. (2008). Reimagining chinatown: An analysis of tourism discourse. Tourism Management, 29(5), 1002-1012.

Schellhorn, M., \& Perkins, H. C. (2004). The stuff of which dreams are made: Representations of the south Sea in German-language tourist brochures. Current Issues in Tourism, 7(2), 95-133.

Selwyn, T. (1996). Introduction. In T. Selwyn (Ed.), The tourist image: Myths and myth-making in tourism (pp. 1-32). Chichester: John Wiley and Sons.

Sharma, M., Jackson, M., \& Inbakaran, R. (2008). Promoting indigenous food to foreign visitors: An Australian study. Asian Anthropology, 7(1), 121-134.

Silver, I. (1993). Marketing authenticity in third world countries. Annals of Tourism Research, 20(2), 302-318.

Silvén, E. (2012). Contested sami heritage: Drums and sieidis on the move. In: National museums and the negotiation of difficult pasts conference proceedings from EuNaMuS, identity politics, the uses of the past and the European citizen (pp. 173-186). Linköping: Linköping University Electronic Press.

Steiner, C. J., \& Reisinger, Y. (2006). Understanding existential authenticity. Annals of Tourism Research, 33(2), 299318.

Taylor, J. P. (2001). Authenticity and sincerity in tourism. Annals of Tourism Research, 28(1), 7-26.

Timothy, D. J., \& Boyd, S. W. (2006). Heritage tourism in the 21st century: Valued traditions and new perspectives. Journal of Heritage Tourism, 1(1), 1-16.

Tuulentie, S. (2006). The dialectic of identities in the field of tourism. The discourses of the indigenous sámi in defining their own and the tourists'. Identities. Scandinavian Journal of Hospitality and Tourism, 6(1), 25-36.

Vahid Dastjerdi, H., Davoudi-Mobarakeh, S., \& Zare, M. (2012). A multimodal analysis of differences between TV commercials and press advertisements: A discoursal study of persuasion-seeking strategies in the mass media. Studies in Literature and Language, 4(2), 115-121.

Valkonen, J., \& Valkonen, S. (2014). Contesting the nature relations of sami culture. Acta Borealia, 31(1), 25-40.

Viken, A. (2006). Tourism and sámi identity - An analysis of the tourism-identity nexus in a sámi community. Scandinavian Journal of Hospitality and Tourism, 6(1), 7-24.

Viken, A., \& Müller, D. K. (2006). Introduction: Tourism and the sámi. Scandinavian Journal of Hospitality and Tourism, 6(1), 1-6.

Viken, A., \& Müller, D. K. (2017). Indigeneity and indigenous tourism. In A. Viken \& D. K. Müller (Eds.), Tourism and indigeneity in the Arctic (pp. 16-32). Bristol: Channel View Publications.

Vladimirova, V. K. (2011). "We are Reindeer People, We Come from Reindeer." Reindeer herding in representations of the Sami in Russia. Acta Borealia, 28(1), 89-113.

Waitt, G. (1997). Selling paradise and adventure: Representations of landscape in the tourist advertising. Australian Geographical Studies, 35(1), 47-60.

Waitt, G. (1999). Naturalizing the 'primitive': A critique of marketing Australia's indigenous peoples as 'hunter-gatherers.' Tourism Geographies: An International Journal of Tourism Space, Place and Environment, 1(2), $142-163$.

Wang, N. (1999). Rethinking authenticity in tourism experience. Annals of Tourism Research, 26(2), 349-370.

Wang, Y., Huang, S., \& Kim, A. K. (2015). Toward a framework integrating authenticity and integrity in heritage tourism. Journal of Sustainable Tourism, 23(10), 1468-1481.

Waterton, E., Watson, S., \& Silverman, H. (2017). An introduction to heritage in action. In H. Silverman, E. Waterton, \& S. Watson (Eds.), Heritage in action: Making the past in the present (pp. 3-16). Cham, Switzerland: Springer.

Whitford, M., \& Ruhanen, L. (2016). Indigenous tourism research, past and present: Where to from here? Journal of Sustainable Tourism, 24(8-9), 1080-1099.

Wilson, N. (2014). Managing authenticity. Journal of Critical Realism, 13(3), 286-303. 
Yeoman, I., Brass, D., \& McMahon-Beattie, U. (2007). Current issue in tourism: The authentic tourist. Tourism Management, 28(4), 1128-1138.

Zhu, Y. (2012). Performing heritage: Rethinking authenticity in tourism. Annals of Tourism Research, 39(3), 14951513.

Zotzmann, K., \& O’Regan, J. P. (2016). Critical discourse analysis and identity. In S. Preece (Ed.), The routledge handbook of language and identity (pp. 113-128). London: Routledge. 